\section{EVALUATION TRENCH 1 AND WATCHING BRIEF AREAS X AND Y}

The Watching Brief Areas X and Y were located within the south-east quarter of the study area (Illus 2 and 3), and Evaluation Trench 1 was located at the west corner of Area X.

These areas revealed 27 pits, one of which contained burnt human bone from a probable cremation burial. Burnt bone, possibly human, was also recovered from another pit. Other pits contained Early Neolithic pottery and Beaker pottery. There were no stratigraphic relationships between features that would allow for site phasing.

\subsection{Evaluation Trench 1}

A small oval pit $(01 / 001)$, measuring $0.77 \mathrm{~m}$ by $0.62 \mathrm{~m}$ by $0.16 \mathrm{~m}$ deep and filled with a dark brown/black sandy silt (01/002), contained charcoal inclusions, heat-cracked stones and burnt human bone. The pit is likely to be the remains of an unaccompanied cremation burial, the burnt stones and charcoal deriving from the pyre material. The bone returned a date of 1055-914 cal вс (95\% probability; UBA-15227), placing it in the Late Bronze Age (LBA). The individual's remains were too fragmentary to assign age and sex. It is probable that the individual was associated with the contemporary settlements at Blackford.

\subsection{Area X}

Twenty-one pit features were identified in this area. They varied in size from $0.22 \mathrm{~m}$ by $0.1 \mathrm{~m}$ by $0.08 \mathrm{~m}$ deep (052), to $1.96 \mathrm{~m}$ by $1.6 \mathrm{~m}$ by $0.5 \mathrm{~m}$ deep (019). These features were oval or circular in plan, and

(4a)

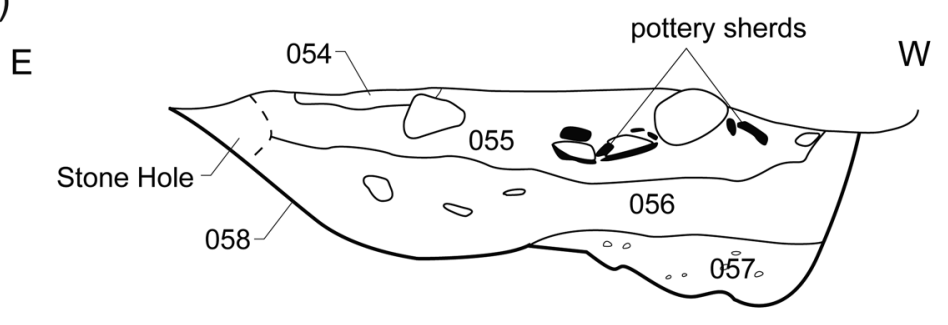

(4b)

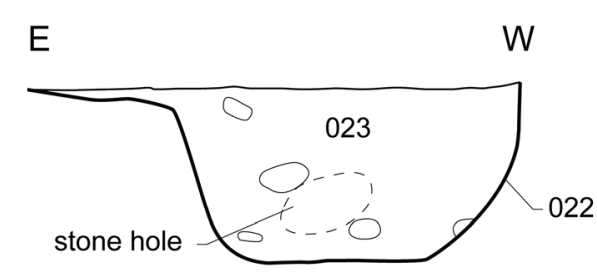

(4c)

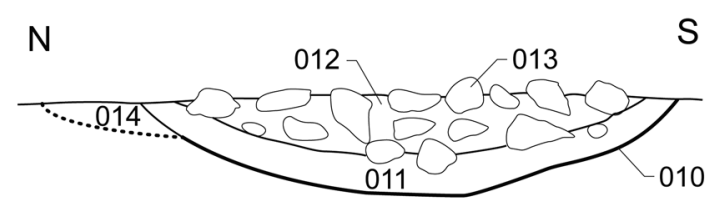

(4d)
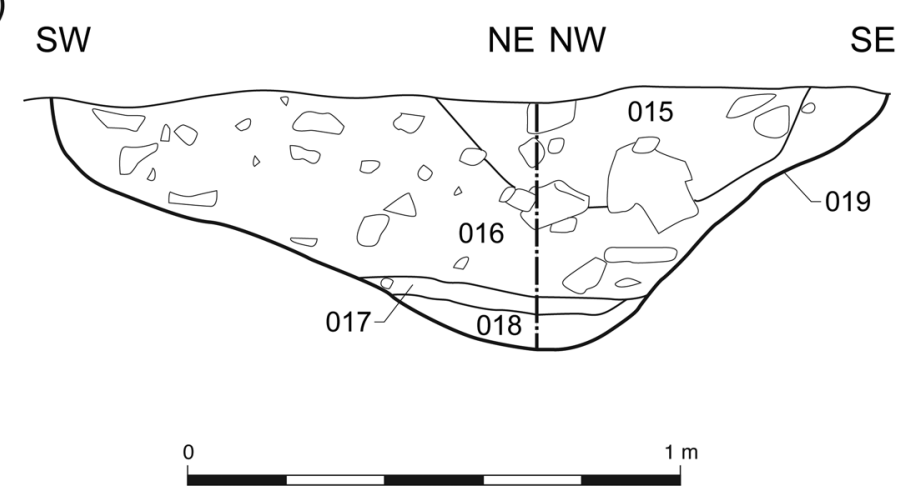

Illus 4 Sections, Trench 1 and Area $X$ 
predominantly contained a single fill. All features were cut into the orange-brown sandy gravel subsoil and sealed by dark brown silty sand topsoil. Five pits contained artefacts, which are summarised below. There was no interpretable pattern indicative of relationships between features, other than that they occupied an area of relatively flat ground (Illus 3).

\subsubsection{Pit 058}

Pit 058 was oval in plan, measured $0.9 \mathrm{~m}$ by $1.44 \mathrm{~m}$ by $0.48 \mathrm{~m}$ deep and contained four fills (Illus $4 \mathrm{a}$ ). The primary fill (057) of orange-brown sandy silt contained $<1 \%$ charcoal inclusions. The secondary fill (056) was a mid-brown to orange silt with $<1 \%$ charcoal and small cobble inclusions. The tertiary fill (055) was firmly compacted greyish-pink sandy silt with $2-3 \%$ small to medium cobbles. It produced 91 sherds of pottery, the majority of which were from a single Early Neolithic vessel, the earliest prehistoric find at Blackford (see Johnson below, Section 3.4). The upper fill (054) was a deposit of loosely compacted mid-brown to black sandy silt with $1 \%$ charcoal inclusions.

The pottery, found in the tertiary fill of the pit, indicated that the pit had already been partially filled before the deposition of the pottery. The primary fill was thought to be the product of the eroding base of the pit, perhaps indicating that the feature was excavated and left open for a short time. The secondary fill may have been naturally deposited, as it appears to have slumped from the sides of the pit. The profile of the tertiary fill suggests that the pit may have been re-cut, and had subsequently become filled with Deposits 055 and 054 , including the pottery sherds.

\subsubsection{Pit 022}

Pit 022 was a circular shallow pit with a diameter of $0.45 \mathrm{~m}$, and was $0.08 \mathrm{~m}$ deep. It held a single fill of loose brown-orange silt and two large sub-rounded stones (023 Illus 4b). Recovered from the pit were fragments of burnt bone, possibly human, and eight sherds from four different Beaker vessels.

Even if the burnt bone was human, it is unlikely that this pit represents an in-situ cremation burial as there were fragments of four different Beaker vessels within the fill. The bone was very abraded and may have undergone a long period of exposure and weathering, and, if human, may have derived from a cremation pyre or cremation burial disturbed before it became deposited within the pit.

The lack of pottery within most of the other pits in this area makes this pit unusual. If the pottery derived from a background scatter of sherds in the area then one would expect the material would have been deposited within more pits. The interpretation proposed here is that Pit 022 represents a structured deposit; the pit was excavated and the fill, along with the pottery, was placed back in the pit within a very short time, as the pit showed no signs of weathering on its edges. Charred grain from the pit returned dates of 2466-2236 cal вс (95\% probability; UBA-15211) and 2343-2153 cal вС (95\% probability; UBA-15212), which accords well with the accepted date range of the Beaker pottery fragments: $2500-2100$ cal BC (see Johnson, Section 3.4 below).

\subsubsection{Pits 006,010 and 019}

These three pits all contained heat-affected deposits. Pit 006 was oval in plan and measured $0.4 \mathrm{~m}$ by $0.5 \mathrm{~m}$ by $0.13 \mathrm{~m}$ deep. It had a concave profile and contained a single fill of charcoal-rich grey-black silty sand. The discoloration of the subsoil was suggestive of in-situ burning.

Pit 010 was a large circular feature with a diameter of $1.1 \mathrm{~m}$ and was $0.2 \mathrm{~m}$ deep. Its profile was bowl-shaped and it was lined with a deposit of charcoal-rich black silt, 011 (Illus 4c). Overlying this was a deposit predominantly made up of burnt and fire-cracked stones (013) in a brown silt matrix (012). This matrix was thought to derive from the topsoil that had sifted down through the loosely compacted burnt stones. On the northern edge of the pit was a small area of heat-affected natural soil (014).

Pit 019 was sub-circular in plan and concave in profile, and measured $1.96 \mathrm{~m}$ by $1.6 \mathrm{~m}$ by $0.5 \mathrm{~m}$ deep. This pit was filled with four deposits (Illus 4d). The lower primary fill (018) was of black sandy silt with charcoal flecks. The secondary fill (017) was a thin band of reddish-orange gravel and was interpreted as redeposited natural subsoil. The tertiary fill, 016 , was a loosely compacted dark brown to black sandy fill with inclusions of charcoal and angular stones. The upper fill, 015, possibly the fill of a re-cut, was 
mid-brown sandy silt with stone inclusions and possibly derived from the topsoil.

The fire-cracked stones and deposits containing charcoal in these pits suggests that fires were being lit in the vicinity and the material from these fires became incorporated into the fill of the pits. In the case of Pit 006 the discoloured subsoil was suggestive of in-situ burning, but for Pits 010 and 019 no such conclusion can be drawn as no such discolouration was recorded.

The purpose of these pits may have been related to a cremation process, or cooking and food preparation, or simply to generate warmth. However, the pits did not contain any burnt animal or human bone. Pit 019 was analysed for charred grain but none was found. However, if food was being cooked in these pits then it may have been cooked in vessels or, in the case of meat, roasted bound in leaves within the embers, limiting the possibility of food material making its way into the burnt deposits. Ethnographic studies of the Maori of New Zealand have described how meat was wrapped in leaves and cooked over a pit of hot stones (Firth 1957: 94). At Lamb's Nursery, Dalkeith, Cook (Cook 2000) excavated a pit containing shattered stones and charcoal close to a Neolithic settlement, although the pit itself was undated.

\subsection{Area Y}

The five features discovered ranged in size from $0.3 \mathrm{~m}$ by $0.1 \mathrm{~m}$ by $0.1 \mathrm{~m}$ deep (022) to $0.44 \mathrm{~m}$ by $0.4 \mathrm{~m}$ by $0.21 \mathrm{~m}$ deep (029). Although the Area Y features were closely clustered, they do not show any spatial patterning recognisable as a structure and, as with Area X, there was no interpretable pattern indicative of relationships between features, other than that they occupied an area of relatively flat ground (Illus 3 ). The purpose, date of excavation and infilling remain undetermined. Only Pit 026 contained any finds: a small quantity of calcined bone.

\subsection{Pottery}

\section{Melanie Johnson}

Two features within Watching Brief Area X produced pottery, Pits 022 and 058 (Illus 3).

Pit 022 contained eight sherds $(68 \mathrm{~g})$ from four different Beaker vessels (P185-188). Three of the vessels were represented only by body sherds while the fourth (P187) comprised a rim; this was flaring with a rounded top. Two (P187-188) were decorated with impressed twisted cord (All-Over Corded, AOC). The fabrics were fine and sandy, with well smoothed or polished surfaces. Fragments of abraded burnt bone, which is possibly human (see Section 3.5), were also found in this fill. The accepted date range for these vessels is 2500/2400 BC to 2200/2100 BC (Sheridan 2007). AOC Beakers are found in a variety of funerary and non-funerary contexts.

Pit 058 contained 91 sherds (weighing $516 \mathrm{~g}$ ). The majority were from a single vessel (P189) from Fill 055, with a single small abraded sherd from Fill 056. P189 was in very poor condition, abraded, badly cracked and possibly burnt, and included a number of neck and possible flaring rim sherds. The fabric was sandy and fine, red-brown in colour, and with walls up to $8 \mathrm{~mm}$ thick. The surfaces had been well smoothed, with evidence to suggest the exterior had been polished. There was sooting on the interior. This vessel appears to be Early Neolithic in date, the sherds representing a plain, flaring rimmed round-bottomed bowl. It is unclear whether it was carinated as it was too fragmentary, so it is difficult to pinpoint its date or vessel type any more closely.

Both of these features, and the earlier prehistoric pottery contained therein, do not relate to the Bronze and Iron Age occupation across other areas of the site, but indicate that earlier activity was taking place at other locations within the development area, as they pre-date any of the excavated structures.

\subsection{Environmental evidence}

\subsubsection{Calcined bone}

Sue Anderson

A possible cremation burial was identified during the Phase 1 evaluation (01/002). Hand-collected burnt bone totalled $23.2 \mathrm{~g}$ and was human. Identified fragments included pieces of skull (maximum dimension $23 \mathrm{~mm}$ ), tibia (max $\operatorname{dim} 35 \mathrm{~mm}$ ), femur and humerus. A full quantification is included in the archive.

Pit 022 (Area X) contained 5.4g of burnt bone which was very abraded but possibly human. This was found in association with pottery and the feature may have been a disturbed cremation burial. 


\subsubsection{Plant remains from Area $X$ Mhairi Hastie}

Out of the nine samples processed from this area, only three contained any carbonised cereal grain and other plant remains. The bulk of the cereal grains were recovered from the fills of Pits 028 and 022. Pit 022 was also found to contain fragments of Beaker pottery and some cremated human bone.

The cereal grains were very poorly preserved and much abraded. All of the grains bar two were identified as barley, although none was sufficiently preserved to allow identification of the naked or hulled variety. Two grains of wheat were also recovered; again, preservation was not good and neither could be identified to species level.

A small assemblage of charred hazelnut shell was present in the fill of Pit 022 along with the cereal grain and one or two fragments were recovered from a second pit (035).

Four seeds of wild taxa were recovered from the samples, including two seeds of goosegrass from Pit 022 , and one of nipplewort and a possible pea (Leguminosae indet.), from the fill of Pit 028. All of these species are common weeds of cultivated land and were probably harvested along with the grain.

The abraded nature of the cereal grains suggests that they had undergone some movement prior to being deposited in the pits, suggesting that the grains are unlikely to have been burnt in situ.

\subsection{Radiocarbon dates}

Three dates were returned from Area X that indicate Early and Late Bronze Age activity (Table 2). Pit 022 contained Beaker pottery dated to 2500/2400-2200/2100 BC (Sheridan 2007) and charred grain and a hazelnut shell retrieved from the pit fill returned similar date ranges of 2466-2236 and $2343-2153 \mathrm{cal} \mathrm{вс}$. The cremated individual found in Pit 01/001 most probably died some time between 1055 and $914 \mathrm{cal} \mathrm{BC}$, but this does not necessarily date the infilling of this pit, as the skeletal remains could have been curated before or after the cremation, and/or the burnt bone could have become incorporated into the pit during or after its infilling. The charred cereal grains could have undergone similar taphonomic processes; however, these dates match the dates for the pottery quite closely.

\subsection{Discussion}

Area $\mathrm{X}$ is an area that contained evidence for pit digging and the deposition of cremated remains. Cremation burials are known from both the Neolithic and the Bronze Age. In the Scottish Neolithic the cremation rite is more frequently associated with the west of Scotland and has links to the traditions of the Irish court tombs (Bradley 2007: 60).

At Blackford the cremation burial from Area $\mathrm{H}$ (Section 7) was dated to the Middle Bronze Age/Late Bronze Age (MBA/LBA), and the cremated bone recovered from 01/001 in Trench 1 was dated to the LBA. The small cinerary urn (NN81SE 3) found in $c 1863$ was located some $20 \mathrm{~m}$ from $01 / 001$ (Illus 3, Site 11). Cremated bone was also recovered from Pit 022 (Area X) in association with Beaker pottery and EBA radiocarbon determinations. The contents of neither Pit $01 / 001$ nor Pit 022 are likely to have originated from redeposited pyre material, and the fragments of burnt bone within them were probably burnt elsewhere and became

Table 2 Radiocarbon dates from Area X and Trench 1. Calibration was conducted using OxCal v4.1.7, using the IntCal09 calibration curve

\begin{tabular}{|c|c|c|c|c|c|}
\hline Lab no. & Material & Context description & Date BP & $95 \%$ probability & $\delta^{13} \mathrm{C} \%$ \\
\hline \multicolumn{6}{|l|}{ Area X } \\
\hline UBA-15211 & Hazelnut shell & Fill of Pit 022 & $3876 \pm 26$ & $2466-2236$ вс & -25.1 \\
\hline UBA-15212 & Barley indet. & Fill of Pit 022 & $3820 \pm 21$ & $2343-2153$ вС & -25.3 \\
\hline \multicolumn{6}{|c|}{ Trench 1} \\
\hline UBA-15227 & Cremated bone & Fill of Pit $01 / 001$ & $2836 \pm 23$ & $1055-914$ вс & -18.4 \\
\hline
\end{tabular}


incorporated into the fills of these pits, either as a result of deliberate deposition or by means of natural processes. Either is possible given the small quantities of bone present.

The deposition of Early Neolithic pottery in Pit 058 may have been intentional. The structured deposition of pottery sherds in various contexts is a common occurrence in the Neolithic (Thomas 1999: 64; Chapman 2000; Pollard 2001). The tradition may have continued into the EBA here, with the deposition of Beaker pottery within Pit 022. 